\title{
Determination of the Gram Type Using the Reaction Between Polymyxin B and Lipopolysaccharides of the Outer Cell Wall of Whole Bacteria
}

\author{
By J. WIEGEL*† AND L. QUANDT \\ Institut für Mikrobiologie der Universität Göttingen, Grisebachstr. 8, 3400 Göttingen, Federal \\ Republic of Germany
}

(Received 25 November 1981; revised 1 March 1982)

\begin{abstract}
The polymyxin B-dependent formation of protrusions (blebs) of lipopolysaccharides on the cell wall of whole bacteria is suggested as a specific reaction for the determination of the Gram type of newly isolated bacteria. A total of 35 different bacterial species from 27 genera were studied as well as the influence of various test parameters. The reaction was specific: all 13 species of the positive Gram type gave a negative reaction, but all bacteria of the negative Gram type gave a distinct positive reaction.
\end{abstract}

\section{INTRODUCTION}

Originally, the Gram staining method with triphenylmethane and iodine was used to visualize bacteria in tissues (Gram, 1884). It was soon established that this method divided bacteria into two groups: those which retained the stain (Gram-positive) and those which could be decolorized with alcohol (Gram-negative). Several variations have been published which should lead to more reliable staining procedures (e.g. Magee et al., 1975; Bartholomew, 1962; Diena et al., 1962). The mechanism of the staining reaction is still not fully understood. However, it is known that the differential staining response correlates not only with differences in cell wall structure but also, in general, with many other properties (Lamanna et al., 1973), including aminopeptidase activity (Cerny, 1978) and the size and regulation of the citrate synthase (Weitzman \& Jones, 1975). The differentiation by Gram staining has grown in importance as a taxonomical property and a systematic term. There are a number of organisms for which the results of the Gram staining reaction are variable or, and this is more important, contradict their taxonomic classification. Therefore, a differentiation between the term describing the results of the staining reaction (Gram reaction positive/negative/variable), and the systematic term based on a classification according to biochemical properties (Gram type positive/negative), has been suggested (Wiegel, 1981). This led to the need for methods other than the Gram staining procedure. One property which completely separates organisms of the positive and negative Gram type is the presence of lipopolysaccharides (LPS) in the outer cell wall of the negative type.

In recent years, a number of publications have dealt with the determination of LPS (also termed endotoxin or pyrogen) by the Limulus-lysate test (Levin \& Bang, 1968) and its variations (e.g. Maeda \& Taga, 1979; Flowers, 1979; Coates, 1977; Janda \& Work, 1971). This extremely sensitive test is used mainly to detect bacteria in medical fluids. Its use for taxonomic purposes may give questionable results: a slight LPS contamination of any solutions used, even in the absence of viable bacteria, can give a positive result. A specific reaction of LPS with the basic cyclic polypeptide antibiotic polymyxin B (Newton, 1956), has been documented, e.g. for Escherichia coli (Bader \& Teuber, 1973), Serratia marcescens (Brown \& Tsang, 1977) and Pseudomonas aeruginosa (Newton, 1953; Koike et al., 1969). Koike \& Iida (1971) demonstrated that polymyxin B forms a complex with the LPS, but does not react with lipoproteins of $E$. coli and

† Present address: Department of Microbiology, University of Georgia, Athens, GA 30602, U.S.A. 
Salmonella typhimurium. The formation of a complex between LPS and polymyxin B results in the formation of blebs (protrusions) on the cell surface, which are easily seen using the electron microscope (Schindler \& Teuber, 1975; Lounatmaa et al., 1976; Koike et al., 1969; Wiegel \& Mayer, 1978). Bleb formation is not an artefact produced during fixation of detergent-weakened membranes: the blebs are evaginations of the cell surface monolayer due to the formation of the LPS-polymyxin B complex (Schindler \& Teuber, 1975).

In this paper we report a standardized application of the LPS-polymyxin B reaction to various bacteria. Since the method has proved to be reliable, specific and very sensitive, we suggest that it may be used for the differentiation of Gram type positive and negative bacteria, especially for the classification of new bacteria and in cases where other tests give questionable results.

The application of this method has led to the reclassification of Corynebacterium autotrophicum, now Xanthobacter autotrophicus (Wiegel \& Mayer, 1978; Wiegel et al., 1978).

\section{METHODS}

Bacteria and culture conditions. The bacteria investigated are listed in Table 1. Most were obtained from the Deutsche Sammlung von Mikroorganismen (DSM). The growth conditions were as indicated in the DSM catalogue (Deutsche Sammlung von Mikroorganismen, 1977); however, if possible, liquid or agar-containing medium with peptone, yeast extract and glucose was employed.

Incubation with polymyxin B. Bacteria were suspended in $1 \mathrm{ml} 10 \mathrm{mM}$-Tris/ $\mathrm{HCl}$ buffer, $\mathrm{pH} 7 \cdot 2$, which, in the case of halophilic bacteria, was supplemented with up to $25 \%$ (w/v) NaCl to prevent lysis. Samples $(0.25 \mathrm{ml})$ of this suspension were incubated at $35^{\circ} \mathrm{C}$ (thermophiles at $50^{\circ} \mathrm{C}$ ) in the presence of 0 (control), 160 and 1000 units

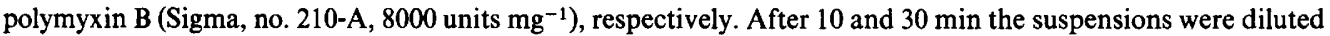
with cold $\left(0^{\circ} \mathrm{C}\right) \mathrm{Tris} / \mathrm{HCl}$ buffer $(10 \mathrm{mM}, \mathrm{pH} \mathrm{7.2})$ and the cells centrifuged at $3000 \mathrm{~g}$ for $5 \mathrm{~min}$. Cells were washed once to remove free or loosely-bound polymyxin, and then resuspended in $\mathrm{Tris} / \mathrm{HCl}$ buffer to give a slightly turbid suspension. This suspension was used immediately or within $8 \mathrm{~h}$ for electron microscopy.

The influence of various test parameters was investigated with selected bacteria. These were Xanthobacter autotrophicus (DSM 432, 2267), a species which has an extremely low LPS content and shows an indistinct Gram staining reaction, a 'Salmonella minnesota' mutant with a rudimentary LPS, an Alcaligenes eutrophus strain (three species of the negative Gram type), and Bacillus megaterium as a representative of the positive Gram type. The parameters tested and the results were:

(1) Incubation time. No basic differences in bleb formation were observed between 3 and 60 min incubation. Incubation can therefore be reduced to 3-5 min if desired (see also Schindler \& Teuber, 1975).

(2) Incubation temperature. No significant difference was observed when temperature was varied between 20 and $45^{\circ} \mathrm{C}$ when testing mesophiles $\left(37\right.$ to $60^{\circ} \mathrm{C}$ for the thermophilic Thermoanaerobacter ethanolicus).

(3) Growth stage of the cells. Early- and late-exponential and early- and late-stationary growth phase liquid cultures were tested. Only the cells of the late-stationary phase tended to lyse during negative staining, otherwise the age of the cells was of little significance in bleb formation. However, the use of cells from colonies (not too old) on agar medium is recommended; all growth phases are represented and cells from the agar surface show less debris after negative staining than those from liquid cultures.

(4) Time of storage at $0-4^{\circ} \mathrm{C}$ between polymyxin $\mathrm{B}$ treatment and negative staining. No difference was observed up to $8 \mathrm{~h}$ of storage, but some bacteria tended to lyse when stored for over $20 \mathrm{~h}$ after treatment with the high polymyxin B concentration.

(5) Test volume. Using single colonies, the test volume could be reduced to as little as $50 \mu \mathrm{l}$ in Eppendorf reaction vials without difficulty.

(6) Polymyxin concentration. It was important to vary the concentration of polymyxin B from 0 to 2000 units $\mathrm{ml}^{-1}$, as bleb formation was dependent on polymyxin B concentration (Fig. 1). For example, with Xanthobacter autotrophicus $80-240$ units of polymyxin gave ambiguous results, but good bleb formation was obtained with 800 units. In some cases, high concentrations of polymyxin caused cell lysis (e.g. Thermoanaerobacter ethanolicus of the positive Gram type), or the blebs separated from the cells (e.g. Citrobacter). Therefore, two concentrations of polymyxin (in addition to the zero-control) are recommended: 160 and 1000 units (ml cell suspension) ${ }^{-1}$.

Electron microscopy. Negative staining was performed as described by Beuscher et al. (1974) and Valentine et al. (1968) using $3 \%(\mathrm{w} / \mathrm{v})$ uranyl acetate $(\mathrm{pH})$ dissolved in water. Electron micrographs were taken with a Philips EM 301 electron microscope. Sizes were calibrated with a cross-lined grating replica. Acceleration voltage was $80 \mathrm{kV}$. Electron microscopic examination of the samples was done in a random order to minimize the possibility of biased interpretation of the bacteria examined.

Gram staining reaction. The Difco kit was used for Gram staining, but with propanol decolorization (Bartholomew, 1962). 
Table 1. Bacterial strains investigated

(a) Bacteria of negative Gram type

Rhodospirillum rubrum HA (DSM 107)

Rhodopseudomonas capsulata Kbl (DSM 155)

Rhodopseudomonas gelatinosa (DSA 149)

Chlorobium limicola (DSA 249)

Xanthobacter autotrophicus 7c (DSM 432); JW21; JW33 (DSM 1618); JW50

Azotobacter vinelandii (DSM 85)

Beijerinckia mobilis (DSM 1720)

Derxia gummosa (DSM 723)

Rhizobium meliloti (DSM 30135)

Pseudomonas pseudoflava (DSM 1034)

Alcaligenes eutrophus H16; N9A (DSM 428; DSM 518)

Citrobacter freundii (DSM 30039)

'Salmonella minnesota' R595 (E. Rietschel, Freiburg)

Escherichia coli K12 (DSM 498)

Chromobacterium violaceum (DSM 30191)

Proteus mirabilis (DSM 30118)

Bacteroides amylophilus (DSM 1361)

Neisseria meningitidis (P.R.G. Schindler, München)

Acinetobacter calcoaceticus (DSM 586)

(b) Bacteria of positive Gram type

Bacillus megaterium (DSM 32)

Bacillus brevis (DSM 1794)

Clostridium thermoautotrophicum (DSM 1974)

Clostridium thermohydrosulfuricum JW 102

Sporosarcina ureae (DSM 317)

Sporosarcina sp. (courtesy D. Claus, Göttingen)

'Thermoanaerobium brockii' (DSM 1457)

'Nocardia opaca' 1B (DSM 427)



Part in

Bergey's Manual

15

15

15

15

15

15

17

(c) Bacteria of questionable Gram type

Xanthobacter autotrophicus (DSM 432, 1393, 1618, 2267)

( $\leftarrow$ 'Corynebacterium autotrophicum')

Xanthobacter flavus (DSM 338) (־'Mycobacterium flavum' 301)

'Corynebacterium nephridii' (DSM 21150$)(\rightarrow$ ?)

Thermoanaerobacter ethanolicus (ATCC 31550)

Bacillus lentimorbus (DSM 1797)

Desulfotomaculum nigrificans (DSM 574)

Clostridium thermosaccharolyticum (ATCC 7956)

Clostridium cellobioparum (DSM 1351)

Halobacterium halobium (DSM 670)

Gram staining

reaction Gram type

$\begin{array}{cc} \pm /+ & \text { negative } \\ + & \text { negative } \\ \pm & \text { negative } \\ -/ \pm & \text { positive } \\ - & \text { positive } \\ - & \text { positive } \\ - & \text { positive } \\ - & \text { positive } \\ - & \text { zero }\end{array}$

* Buchanan \& Gibbons (1974).

Aminopeptidase test. The test of Cerny (1976) was employed; the indicator strips were a gift from Merck.

Limulus amoebocyte lysate test. The determination of LPS with the Limulus-lysate test was done according to Sigma Bulletin 210 using the E-toxate $\mathbf{R}$ test kit.

\section{RESULTS}

\section{Examination of bacteria}

Table 1(a) lists all the organisms investigated which are known for their definite negative Gram type and Gram-negative staining reaction. These bacteria all gave definite bleb formation with polymyxin $\mathbf{B}$, whereas the organisms in Table $1(b)$, representatives of the positive Gram type, gave no reaction with polymyxin $B$. 

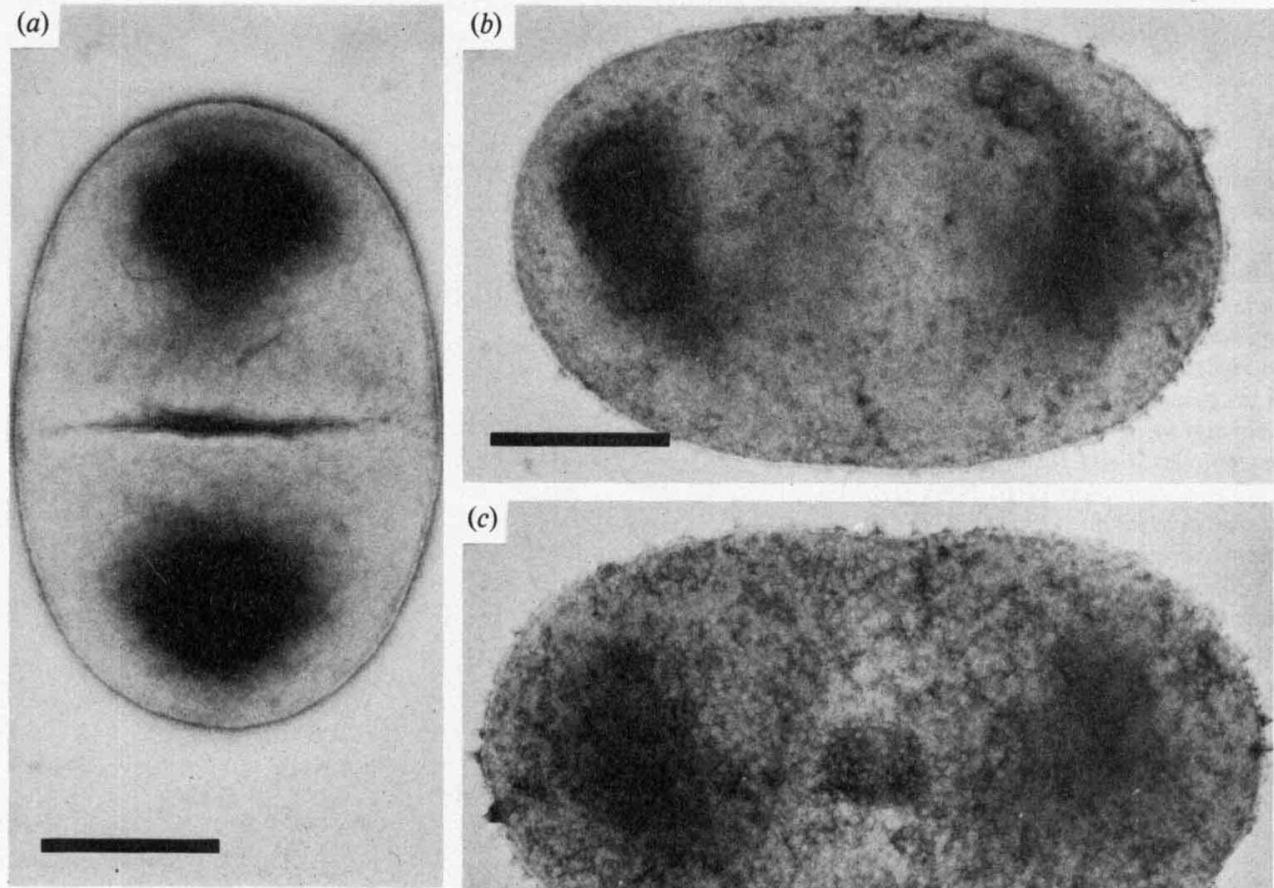

(d)
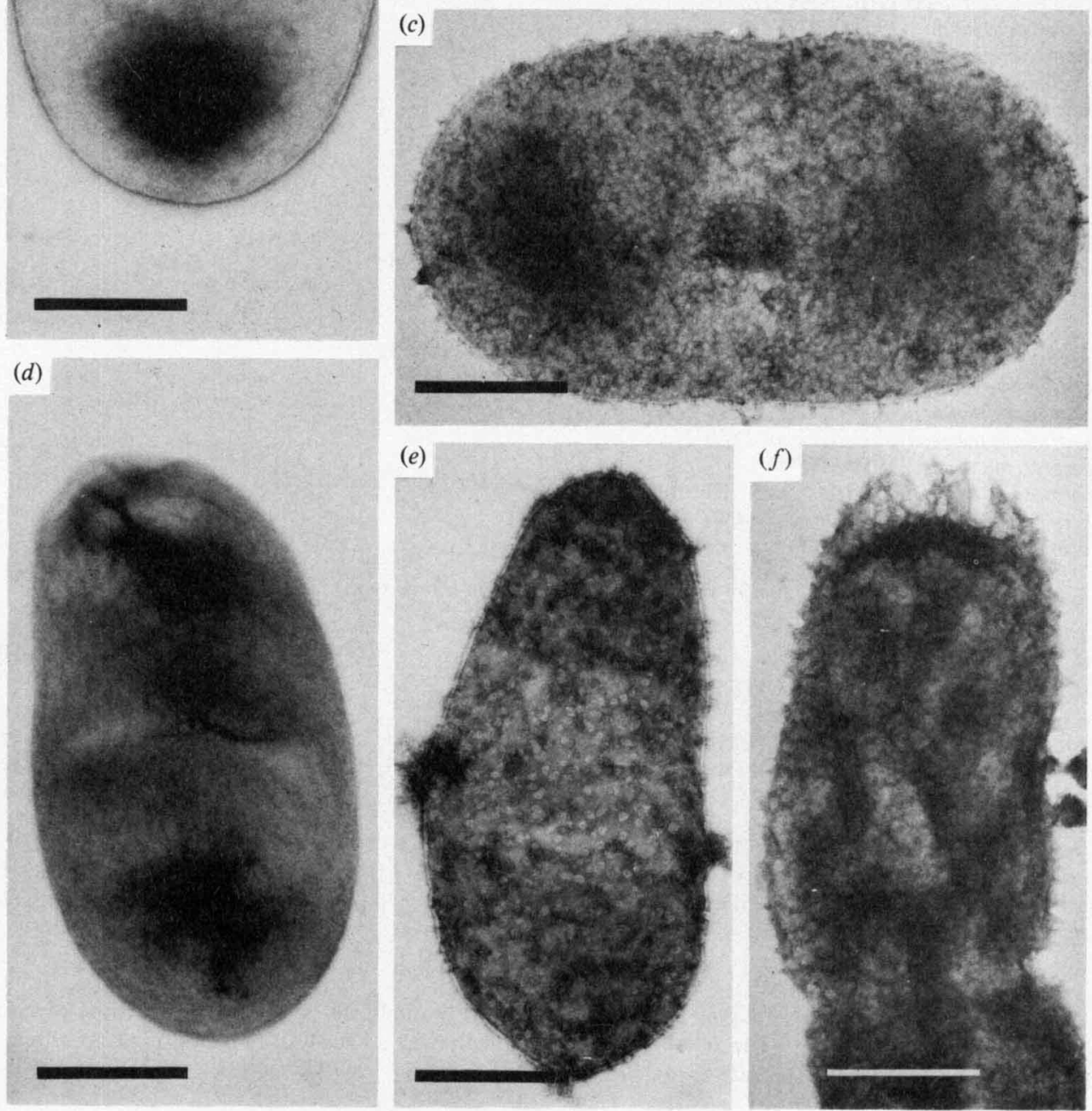

Fig. 1. Bacteria of the negative Gram type treated with increasing amounts of polymyxin B. $(a, b, c)$ 'Salmonella minnesota' R595 treated with 0 (control), 160 or 1000 units, respectively. $(d, e, f)$ Citrobacter freundii treated with 0,160 or 1000 units, respectively. The bar markers represent $0.5 \mu \mathrm{m}$. 
Table 1 $(c)$ gives examples of bacteria for which a Gram staining reaction opposite to their Gram type (systematic classification) is found. Here the polymyxin B-LPS reaction was in accordance with the systematic Gram type. Table $1(c)$ also includes three organisms of the socalled archaebacteria: a halobacterium and two methane-producing bacteria. This group has totally different cell wall types, i.e. a pseudomurein polymer or a peptide polymer, but no murein sacculus, and the cells do not contain LPS (Kandler, 1979; König \& Kandler, 1979). Consequently we could not find bleb formation. Thus a differentiation between a positive and a zero Gram type according to Wiegel (1981) was not possible; this differentiation can only be achieved by cell wall analysis. However, the typical resistance to the common antibiotics that interfere with the synthesis of the murein sacculus may give the first indication of an archaebacterium (Hilpert et al., 1981).

\section{Morphology of the protrusions and interfering structures}

Different organisms gave different blebs, presumably due to the quantity and structure of LPS in the cell wall (Figs 2,3). The size of the blebs varied from 10 to over $100 \mathrm{~nm}$ in length, depending on the organism and the polymyxin concentration.

Although the morphology of the blebs varied, there was no problem in differentiating between polymyxin-dependent bleb formation and other structures of the outer cell wall layers when a control with $0 \mu \mathrm{g}$ polymyxin was included. For example, Neisseria meningitidis always shows bleb-like structures of the outer cell wall (Morse et al., 1979), but even the so-called polymyxin-insensitive strains (courtesy of Dr P. R. G. Schindler, München, F.R.G.) gave definite positive responses with 160 and 1000 units polymyxin B. Also, the 'polymyxin-resistant' Proteus mirabilis gave a positive reaction.

The possibility of interference by slime structures was tested. The slime-forming strains JW33, 7c and the slime-less mutant $7 \mathrm{c} / \mathrm{SF}$ of Xanthobacter autotrophicus (representative of the Gram type negative bacteria) and Bacillus megaterium (an example of a slime-producing Gram type positive bacterium) were selected. Slime could be clearly differentiated from blebs in the negatively stained preparation examined at higher magnification (Fig. 3). High concentrations of polymyxin B may damage the cytoplasmic membrane, resulting in a release of cytoplasm. However, as already shown with Pseudomonas aeruginosa (Koike et al., 1969), the released cytoplasm could be easily differentiated from blebs produced by the reaction of LPS with polymyxin B.

'Salmonella minnesota' R595 (chemotype Re), a mutant which has one of the most rudimentary LPS-structures so far known, gave a definite reaction with polymyxin B (Fig. $1 a-c$ ). However, the number and size of the blebs were reduced, in accordance with the results of Schlecht \& Fromme (1980) and Schindler \& Teuber (1975) using a mutant of the chemotype Rc of $S$. typhimurium. HsuChen \& Feingold (1973) reported that polymyxin B reacted with phosphatidylethanolamine in artificial membranes. Species of Bacillus and Sporosarcina contain high amounts of this compound (Ikawa, 1967; Lombardi \& Fulco, 1979), but we found no interfering reactions (i.e. no bleb formation) with Sporosarcina sp., S. ureae, Bacillus megaterium, B. lentimorbus and B. brevis. This agrees with the results of Imai et al. (1975) with the lipids of Streptococcus sanguis.

Prefixation of the organisms with glutaraldehyde or formaldehyde did not result in a good staining reaction and/or bleb formation, and is not recommended for the standard test.

\section{Comparison with the Limulus-lysate test}

The bacteria listed in Table 1(c) were subjected to the Limulus-lysate test (Sigma, E-toxate test). The results agreed with those obtained by the polymyxin-LPS test. However, it proved difficult to perform the gel-forming Limulus-lysate test with bacteria producing copious amounts of slime, such as Xanthobacter strains, Rhizobium (grown under $\mathrm{N}_{2}$-fixation conditions) and Bacillus megaterium. These bacteria had to be washed in saline of $\mathrm{pH} 10.5-11.0$ to remove the slime. Gel formation was poor for Xanthobacter and Rhizobium. It is difficult to distinguish between a very low LPS content as found in these organisms and minor contaminations of LPS 

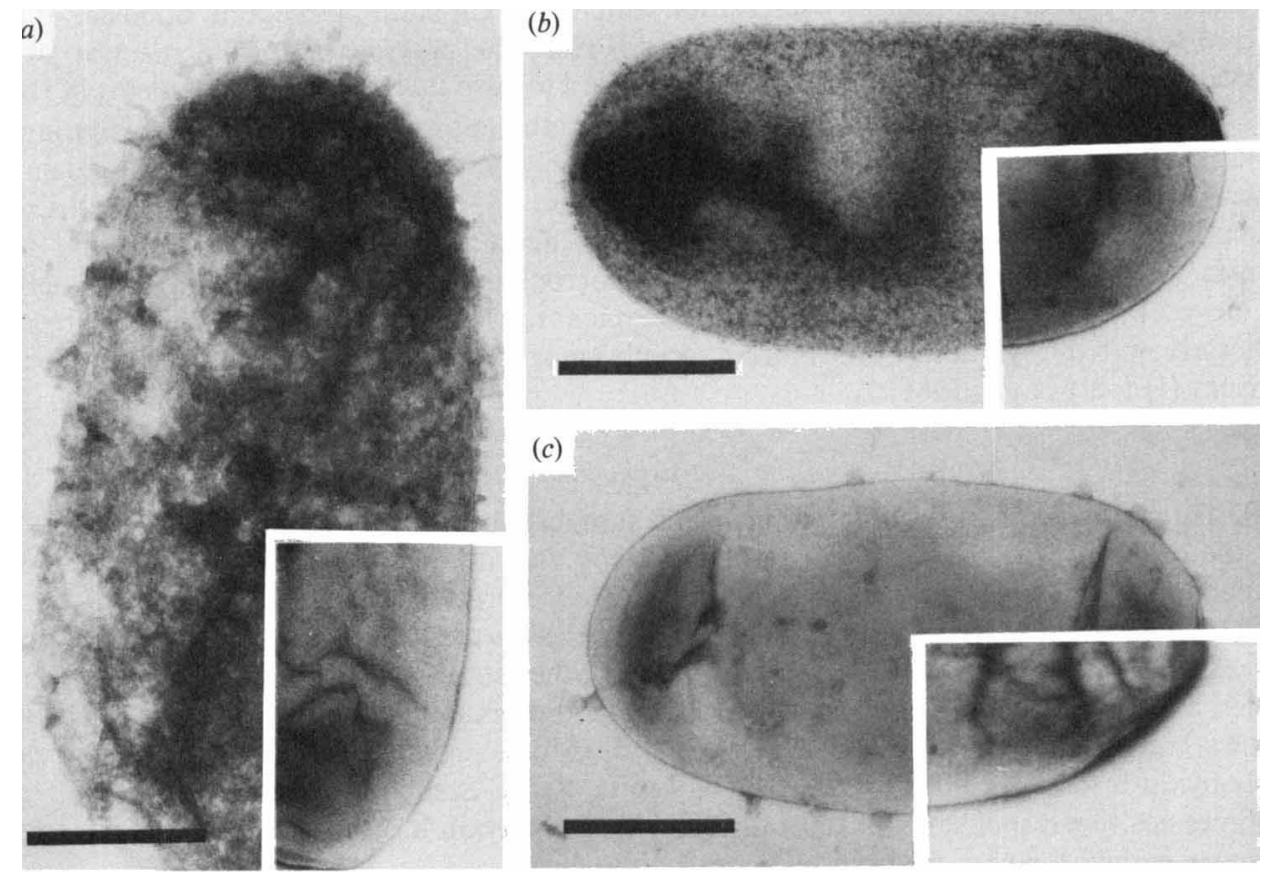

(d)

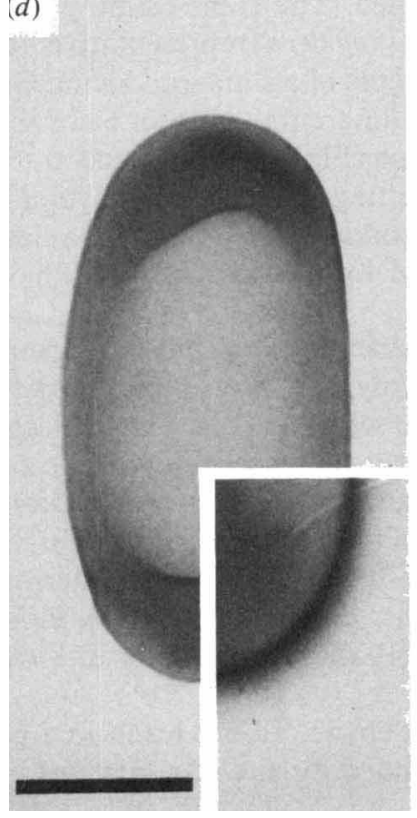

(e)

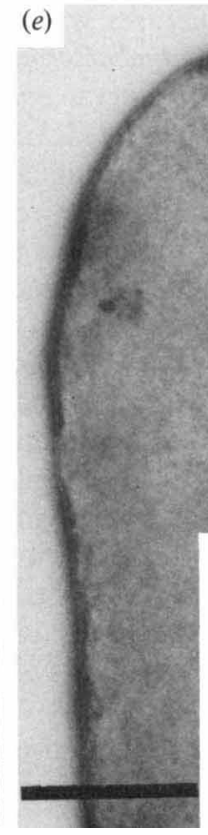

$(f)$

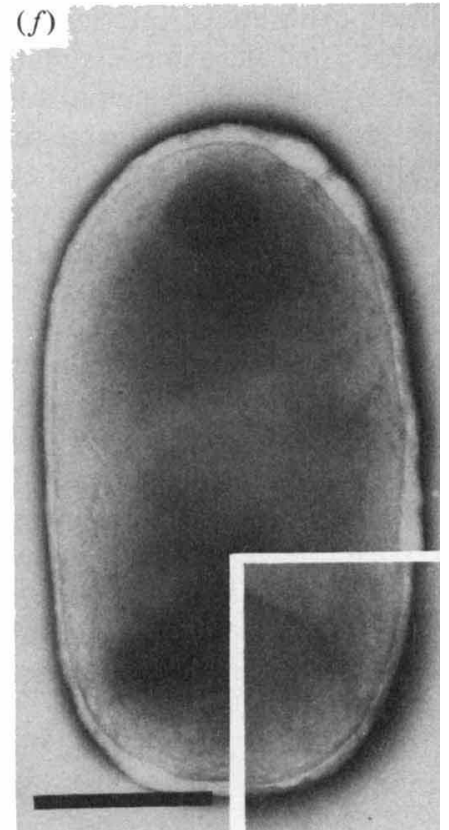

Fig. 2. Bacteria treated with 1000 units or 0 units (control, as inset) polymyxin B. $(a-c)$ Gram type negative with bleb formation: (a) Bacteroides amylophilus, (b) Rhizobium meliloti, (c) Chlorobium limicola. $(d-f)$ Gram type positive with no bleb formation: $(d)$ Bacillus brevis, $(e)$ Clostridium cellobioparum, $(f)$ 'Nocardia opaca' (white areas due to cell shrinkage following evaporation of negative stain). The bar markers represent $0.5 \mu \mathrm{m}$; inset magnification is identical with that of the respective main figure. 

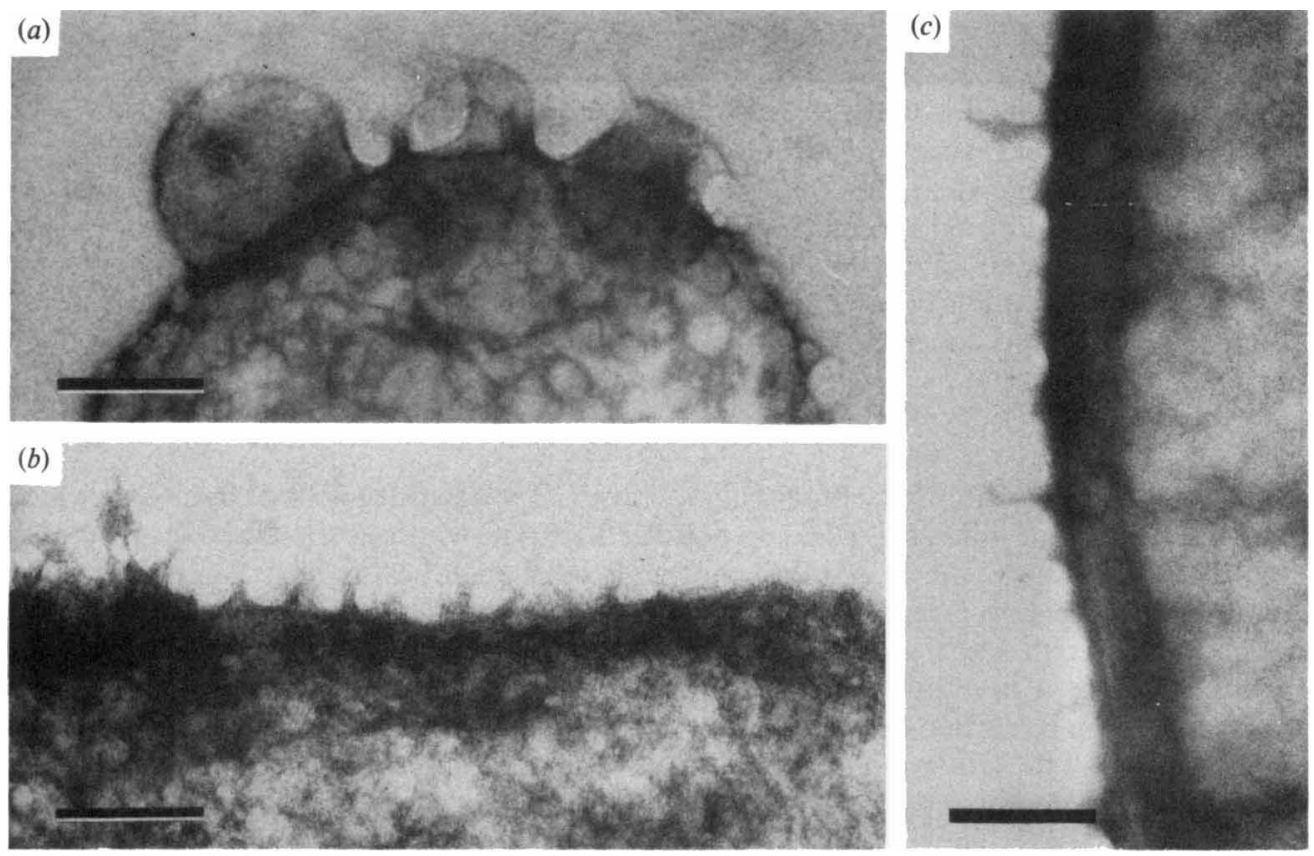

Fig. 3. Comparison of blebs and slime. (a) Blebs, Xanthobacter autotrophicus JW33 (DSM 1618); (b) blebs, Citrobacter freundii; (c) slime, Bacillus megaterium. The bar markers represent $0.2 \mu \mathrm{m}$.

or LPS-containing bacteria; some batches of yeast extract gave a positive reaction with the Limulus-lysate test.

Peptidase test versus the polymyxin-LPS test

Cerny (1976) suggested the determination of the peptidase reaction as a possible replacement for the Gram staining reaction. This method gave questionable or contradictory results with respect to the Gram type of seven species: Xanthobacter autotrophicus, Alcaligenes eutrophus, Derxia gummosa, Beijerinckia mobilis, Chlorobium limicola, Bacillus brevis and Sporosarcina ureae. These results are presumably due to factors leading to questionable judgements of the reactions e.g. pigment formation (Otte \& Tolle, 1980), slime production and/or low peptidase activity. Since the test is based on the development of a yellow colour, bacteria with yellow pigmentation and a low peptidase activity would give an indistinct reaction.

\section{$K O H$ test versus the polymyxin-LPS test}

According to Gregersen (1978) only Gram type negative bacteria are lysed when cells are mixed with a $3 \%(\mathrm{w} / \mathrm{v})$ solution of $\mathrm{KOH}$. Due to the liberation of DNA and RNA the cell suspension becomes viscous. If the reaction is positive, the viscous mixture follows an inoculation loop 0.5 to $2 \mathrm{~cm}$ from the surface. Many of the bacteria listed in Table $1(a, b)$ gave a reaction according to their Gram type when subjected to the $\mathrm{KOH}$ test. However some (e.g. Xanthobacter autotrophicus, Gram type negative, or Bacillus megaterium, Gram type positive) gave questionable or wrong results. With several strains of $X$. autotrophicus the controls without KOH treatment were more viscous than the treated cells. Xanthobacter might be more stable to $\mathrm{KOH}$ than other negative Gram type organisms, perhaps due to an additional capsule-like polymer (H. König, O. Kandler \& J. Wiegel, unpublished). This test also gave an indistinct reaction with some extreme thermophilic strains: Thermoanaerobacter and 'Thermoanaerobium', although of the positive Gram type, tended to lyse, thus giving at least a weak positive reaction. Therefore, the test of Gregersen (1978) does not seem to be suitable for the systematic characterization of uncertain isolates from soil or extreme environments or of some slimeproducing bacteria, although it might be a rapid and convenient method for routine analysis. 


\section{Internal controls}

Bacteria with a conspicuous morphology can be recommended as an internal control for bleb formation by mixing these with the suspension of bacteria to be treated with polymyxin $\mathrm{B}$. We found no cross-reactions if such mixed cultures were analysed. Bacillus megaterium, growing as large cells containing no LPS, and Xanthobacter autotrophicus JW21, which grows typically as large branched cell-forms on succinate-supplemented agar, and contains very low amounts of LPS, are suitable as internal control organisms. They are easily grown on nutrient broth agar plates supplemented with $0 \cdot 1 \%$ succinate and can be mixed with the test organism of another morphology in appropriate ratios for the incubation with polymyxin $B$.

\section{DISCUSSION}

Although Newton (1956) has shown that polymyxin B is a surface-active compound which can alter the cell permeability of various organisms, there is no evidence that it produces blebs or bleb-like structures on whole cells with components other than LPS (which is only formed by bacteria of the negative Gram type). More than 30 bacterial species, from various genera described in different Parts of Bergey's Manual of Determinative Bacteriology (Buchanan \& Gibbons, 1974), have been investigated. All bacteria of the negative Gram type tested gave a positive polymyxin B reaction (i.e. bleb formation); all those of the positive Gram type, irrespective of the results of the Gram staining reaction, gave no bleb formation. This demonstrates that the reaction is apparently specific. Therefore electron microscopic examination of the formation of a polymyxin B-LPS complex, which causes a typical evagination of the outer cell wall leaflet, is a valid method in systematic and taxonomic studies for distinguishing between positive and negative Gram type bacteria.

It should be stressed that adapted strains of Pseudomonas aeruginosa grown in the presence of 6000 units polymyxin gave no significant bleb formation; however, if, after such adaptation, these cells were grown in the absence of polymyxin, polymyxin sensitivity was recovered (Gilleland \& Murray, 1976). Nicas \& Hancock (1980) reported that the same organism showed increased polymyxin resistance when grown under $\mathrm{Mg}^{2+}$ limitation. Greenwood (1975) isolated an Escherichia coli strain which was adapted to $24 \mu \mathrm{g}$ (about 160 units) polymyxin. From these results and from the existence of the Salmonella typhimurium mutants obtained by Vaara (1981) one can expect that bacteria might exist with an altered lipid A component or outer cell wall which barely reacts with polymyxin $B$.

Furthermore, we have not proved by analysing the composition of the blebs whether their formation was really due to the interactions of polymyxin B with LPS or with other components. However, although it has been reported that polymyxin reacts with phospholipids and cytoplasmic membranes (Teuber, 1973; Imai et al., 1975), none of the bacteria of the positive Gram type investigated showed bleb formations similar to those described for the bacteria of the negative Gram type. Therefore, further investigations are required of bacteria of the positive Gram type, and a detailed biochemical analysis of the blebs induced by polymyxin on the outer cell wall of bacteria of the negative Gram type.

The polymyxin B-LPS test offers several advantages over methods published for the differentiation of bacteria of the negative Gram type from those of the positive Gram type as follows. (1) The Gram type classification is based on the presence or absence of an essential cell wall component of the negative Gram type bacteria, as opposed to the activity or properties of enzymes such as peptidase or citrate synthase. (2) Direct examination of single cells excludes a false reaction by minor contaminants, as is possible with other tests for LPS. (3) The assay is very sensitive, as only a single colony is required and an extremely low content of LPS or the presence of a rudimentary LPS still gives definite results. (4) The test is insensitive to interfering substances such as slime, excreted cytoplasm and apparently to lipoproteins. Modifications in temperature, $\mathrm{pH}$, incubation time and variation of salt concentrations (up to $25 \%$, w/v) did not affect the test. (5) The analysis is independent of the growth phase of the cells, although a sample from an agar plate culture is recommended. (6) The assay of several strains can be completed within an hour, at the same time as the electron microscopic examination of the flagellation 
type. (7) No expensive, unstable compounds such as those for the Limulus-lysate test are required, and a time lapse of several hours between the incubation with polymyxin B and electron microscopic examination has no significant influence, since the blebs formed are quite stable. The negatively stained samples can be stored for later re-examination. (8) No LPS has to be isolated prior to the test, as required for the test of Ulitzur et al. (1979).

A light microscopic examination of the bacteria tested using fluorescent derivatives of polymyxin (Newton, 1955; Schindler \& Teuber, 1975) is not recommended, since the direct examination of bleb formation is eliminated. Thus a differentiation between adsorption to other components such as lipoproteins or slime and an actual complex formation between polymyxin B and small amounts of LPS in whole cells could not be guaranteed. Also, the use of polymyxin B-containing agar media, on which LPS-containing bacteria cause a precipitation zone around the colony, lacks the specificity and the ease for direct microscopic examination. However, growing the bacteria on polymyxin B-containing agar might serve as a good preliminary test.

We are grateful for support and fruitful discussions of D. Claus, of the German Collection of Microorganisms, Göttingen, F.R.G. and F. Mayer, Göttingen for permission to use the electron microscopy facilities. This work was supported by a grant (to J. Wiegel) from the Deutsche Forschungsgemeinschaft.

\section{REFERENCES}

BADER, J. \& TEUBER, M. (1973). Action of polymyxin B on bacterial membranes. I. Binding to the antigenic lipopolysaccharide on Salmonella typhimurium. Zeitschrift für Naturforschung C 26, 422-430.

BARTHOLOMEW, J. W. (1962). Variables influencing results and the precise definition of steps in Gram staining as a means of standardizing the results obtained. Stain Technology 37, 139-155.

Beuscher, N., Mayer, F. \& GotTschalk, G. (1974). Citrate lyase from Rhodopseudomonas gelatinosa: Purification, electron microscopy and subunit structure. Archives of Microbiology 100, 307328.

Brown, D. A. \& Tsang, J. C. (1977). Chemical and immunochemical changes induced by polymyxin B on outer membranes from Serratia marcescens. $A b$ stracts of the Annual Meeting of the American Society for Microbiology, A49.

BuchanaN, R. E. \& GibBons, N. E. (editors) (1974). Bergey's Manual of Determinative Bacteriology, 8th edn. Baltimore: Williams \& Wilkins.

CERNY, G. (1976). Method for the distinction of Gram negative from Gram positive bacteria. European Journal of Applied Microbiology 3, 223-225.

Cerny, G. (1978). Studies on the aminopeptidase test for the distinction of Gram negative from Gram positive bacteria. European Journal of Applied Microbiology and Biotechnology 5, 113-122.

COATES, D. A. (1977). Enhancement of the sensitivity of the Limulus assay for the detection of Gram negative bacteria. Journal of Applied Bacteriology 42, 445449.

Deutsche Sammlung von Mikroorganismen (1977). Catalogue of Strains, 2nd edn. München: Gesellschaft für Strahlen- und Umweltforschung mbH.

Diena, B. B., Wallace, R. \& GreenberG, L. (1962). Gram reaction and tetrazolium staining. Canadian Journal of Microbiology 8, 99-103.

Flowers, D. J. (1979). A micro technique for endotoxin assay by using Limulus lysate. Medical Laboratory Science 36, 171-176.

Gilleland, H. E., JR \& Murray, R. G. E. (1976). Ultrastructural study of polymyxin-resistant isolates of Pseudomonas aeruginosa. Journal of Bacteriology 125, 267-281.

Gram, C. (1884). Über die isolierte Färbung der Schizomyceten in Schnitt- und Trockenpräparaten. Fortschritte der Medizin 2, 185-189.

GreENwOOD, D. (1975). The activity of polymyxins against dense populations of Escherichia coli. Journal of General Microbiology 91, 110-118.

GREGERSEN, T. (1978). Rapid method for distinction of Gram-negative from Gram-positive bacteria. European Journal of Applied Microbiology and Biotechnology 5, 123-127.

HilPeRT, R., Winter, J., Hammes, W. \& Kandler, O. (1981). The sensitivity of archaebacteria to antibiotics. Zentralblatt für Bakteriologie, Parasitenkunde, Infektionskrankheiten und Hygiene, Abteilung 1 (Originale C) 2, 11-20.

HsuChen, C.-C. \& Feingold, D. S. (1973). The mechanism of polymyxin $B$ action and selectivity toward biological membranes. Biochemistry 12, 2105-2111.

IKAWA, M. (1967). Bacterial phosphatides and natural relationships. Bacteriological Reviews 31, 54-64.

Imai, M., INOUE, K. \& NoJima, S. (1975). Effect of polymyxin B on liposomal membranes derived from Escherichia coli lipids. Biochimica et biophysica acta 375, 130-137.

JANDA, J. \& WORK, E. (1971). A colorimetric estimation of lipopolysaccharides. FEBS Letters 16, 343.

KANDLER, O. (1979). Zellwandstrukturen bei MethanBakterien. Zur Evolution der Prokaryonten. Naturwissenschaften 66, 95-105.

KoIKE, M. \& IIDA, K. (1971). Effect of polymyxin on the bacteriophage receptors of the cell walls of Gram negative bacteria. Journal of Bacteriology 108, 14021411.

KoIKe, M., IIDA, K. \& Matsuo, T. (1969). Electron microscopic studies on mode of action of polymyxin. Journal of Bacteriology $97,448-452$.

KÖNIG, H. \& KANDLER, O. (1979). $N$-Acetyltalosaminuronic acid a constituent of the pseudomurein of the genus Methanobacterium. Archives of Microbiology 123, 295-299. 
Lamanna, C., Malette, M. F. \& Zimmerman, L. (1973). Basic Bacteriology, its Biological and Chemical Background, 4th edn. Baltimore: Williams \& Wilkins.

LeVIN, J. \& BANG, F. B. (1968). Clottable protein in Limulus: its location and kinetics of its coagulation by endotoxin. Thrombosis Diathesis Haemorrhagica 19, 186-197.

Lombardi, F. J. \& Fulco, A. H. (1979). Two distinct pools of membrane phosphatidyl glycerol in Bacillus megaterium. Journal of Bacteriology 141, 618-625.

LounAtMaA, K., MäKelä, P. H. \& SARVAS, M. (1976). Effect of polymyxin on the ultrastructure of the outer membrane of wild-type and polymyxin-resistant strains of Salmonella. Journal of Bacteriology 127, 1400-1407.

MaEdA, M. \& TAGA, N. (1979). Chromogenic assay method of lipopolysaccharides (LPS) for evaluating bacterial standing crop in seawater. Journal of $A p$ plied Bacteriology 47, 175-182.

Magee, C. M., Rodeheaver, G., Edgerton, M. T. \& EDLICH, R. F. (1975). A more reliable Gram staining technique for diagnosis of surgical infections. American Journal of Surgery, 130, 341-346.

Morse, S. A., Cacciapuoti, A. F. \& Lysko, P. G. (1979). Physiology of Neisseria gonorrhoeae. Advances in Microbial Physiology 20, 251-320.

NewTon, B. A. (1953). The release of soluble constituents from washed cells of Pseudomonas aeruginosa by the action of polymyxin. Journal of General Microbiology 9, 54-64.

Newton, B. A. (1955). A fluorescent derivative of polymyxin: its preparation and use in studying the site of action of the antibiotic. Journal of General Microbiology 12, 226-236.

Newton, B. A. (1956). The properties and mode of action of the polymyxins. Bacteriological Reviews 20, 14-27.

Nicas, T. I. \& Hancock, R. E. W. (1980). Outer membrane protein $\mathrm{H} 1$ of Pseudomonas aeruginosa: involvement in adaptive and mutational resistance to ethylenediaminetetraacetate, polymyxin B, and gentamicin. Journal of Bacteriology 143, 872-878.

OTTE, I. \& TOLLE, A. (1980). Zur Aminopeptidase- und Gram-Reaktion von Bakterien. Milchwissenschaft 35, 215-217.
Schindler, P. R. G. \& Teuber, M. (1975). Action of polymyxin $B$ on bacterial membranes: morphological changes in the cytoplasm and in the outer membrane of Salmonella typhimurium and Escherichia coli B. Antimicrobial Agents and Chemotherapy 8 , 95-104.

SCHLEChT, S. \& Fromme, J. (1980). Growth of Salmonella $\mathrm{R}$-mutants in submersed cultures. 21 . Influence of growth phases on the lipopolysaccharide content of the bacteria and on the chemical composition and serological behavior of the lipopolysaccharides. Zentralblatt für Bakteriologie, Parasitenkunde, Infektionskrankheiten und Hygiene Abteilung 1 (Originale A) 248, 352-367.

Teuber, M. (1973). Action of polymyxin B on bacterial membranes. II. Formation of lipophilic complexes with phosphatidic acid and phosphatidylglycerol. Zeitschrift für Naturforschung C 26, 476-477.

Ulitzur, S., YAGEN, B. \& ROTEM, S. (1979). Determination of lipopolysaccharide by a bioluminescence technique. Journal of Applied and Environmental Microbiology 37, 782-784.

VAARA, M. (1981). Increased outer membrane resistance to ethylenediaminetetraacetate and cations in novel lipid A mutants. Journal of Bacteriology 148, 426-434.

Valentine, R. C., Shapiro, B. M. \& Stadtman, E. R. (1968). Regulation of glutamine synthetase. XII. Electron microscopy of the enzyme from E. coli. Biochemistry 7, 2143-2152.

Weitzman, P. D. J. \& JoNES, D. (1975). The mode of regulation of bacterial citrate synthase as a taxonomic tool. Journal of General Microbiology 89, 187190.

Wiegel, J. (1981). Distinction between the Gram reaction and the Gram type of bacteria. International Journal of Systematic Bacteriology 31, 88.

WIEGEL, J. \& MAYER, F. (1978). Isolation of lipopolysaccharides and the effect of polymyxin B on the outer membrane of Corynebacterium autotrophicum. Archives of Microbiology 118, 67-69.

Wiegel, J., Wilke, D., Baumgarten, J., OPITZ, R. \& SCHLEGEL, H. G. (1978). Transfer of the nitrogenfixing hydrogen bacterium Corynebacterium autotrophicum Baumgarten et al. to Xanthobacter gen. nov. International Journal of Systematic Bacteriology 28, 573-581. 